\title{
Study on the Application of Network Teaching Platform to the Teaching of Course Management Science-Xi'an International University Is Taken for Example
}

\author{
Li Liqin \\ Xi'an International University, \\ Xi'an , Shaanxi 710077 ,China
}

\begin{abstract}
In the teaching of course Management Science, how to effectively make use of network teaching platform is a very important reform. How will be the best effect achieved? On the basis of the network teaching platform system available from Xi'an International University and also by combining with the teaching situation of course Management Science, the existing problems are analyzed and also the related suggestions are proposed, in order to achieve a better teaching effect.
\end{abstract}

\section{Keywords: Network Teaching Platform; Management Science}

\section{Introduction}

In September 2013, Xi'an International University established a network teaching platform system cooperatively with Tsinghua University. The system supports the interactive teaching activities between teachers and students on the Internet and can provide network assisted learning functions such as browsing the guidance materials of the selected courses, raising questions, online testing and discussion-based learning for students. It can provide teachers with network teaching support functions such as releasing elective course information, assigning homework, making courseware, answering questions online, online testing, discussion-based learning, and permanently reserving all sorts of online learning traces and statistics, aiming to expand the teaching space and the view of both teachers and students. So far, the total visitor volume of this system has been up to 1889486 person-times, and the total number of courses has been up to 1326. However, the effective utilization rate of the system among all the teachers and students is not ideal and there are many problems, because it was just opened soon. In this paper, how to make better use of network teaching platform for the teaching of course Management Science is discussed, in order to achieve an ideal teaching effect.

\section{The traditional teaching model of Management Science and its disadvantages}

Teaching model refers to a stable structural form for the process of teaching activities implemented in a certain environment under some teaching thoughts, teaching theories and learning theories. Although the teaching model is helpful for teachers to arrange classroom teaching, it has great disadvantages because it is easy to make teachers become the "master" of teaching, but students do not have chances to think, digest and absorb in the teaching process. As a result, the students' subjective initiative and creative potential are suppressed, and also the teaching effect is not ideal [1].

Besides, the biggest drawback of this teaching process lies in the closure of the teaching model, and it will inevitably affect the full play to the students' learning enthusiasm, initiative and creativity when dozens of students with different learning styles and foundation are gathered together to simultaneously receive the relatively 
fixed teaching contents and progress. Especially for course Management Science requiring practice, it is difficult to cultivate students' competence in autonomously learning management theories and solving the problems in the management activities.

In recent years, in general, the teaching effect of course Management Science was not very ideal in Xi'an International University: the relevant theoretical knowledge of course Management Science has been basically known well by students, but the students' competence in autonomous learning and solving problems is not excellent and still far away from the requirements for the applied and specialized talents.

\section{The advantages of network teaching platform in the teaching of course Management Science}

Based on the disadvantages of the traditional teaching model, it is very necessary and important to introduce network teaching platform to the teaching of course Management Science. The specific advantages of network teaching platform are as follows.

\subsection{Improving students' interest in learning Management Science}

Management Science is a course requiring practice, and therefore, the interaction between teaching and learning, the close connection between knowledge and practice, a good combination in-class and after-class learning, and equal dialogues between teachers and students are more greatly advocated in the whole teaching links of this course. Therefore, it is necessary to change the traditional "closed" and "cramming" teaching concept and actions, aiming to fully improve the teaching quality of Management Science. With the aid of integrated network teaching platform, the teaching contents such as syllabus, experiment guidance, video and records, and reviewing questions are released to the network platform, and the teaching materials are displayed more flexibly and vividly.

\subsection{Enriching the resources for teachers to prepare lessons}

The faculty in Xi'an International University is very insufficient in comparison with that of other key universities. This is mainly because that the teaching team is very young and lacks experience, and some teaching materials are difficult to find and directly affect the teaching effect plus the limitation of the book collection of the library. With the openness of the campus network teaching platform, the resources for teachers to prepare lessons are greatly enriched, and young teachers become very convenient to collect the resources and prepares a lesson. In the past, teachers often needed to look up materials in the library in addition to the reference books in hand. Now, teachers will use a computer to view the shared resources and timely collect the appropriate teaching materials in the process of preparing a lesson, so as to meet the related needs and enrich the teaching contents.

\subsection{Achieving collaborative learning among students}

Collaborative learning is a teaching method, in which a given learning objective is collaboratively completed by some students in order to promote learning. Its core is to promote a group of learners to complete a learning task together. The synchronous discussing function of computer network lets the learners in different regions get involved in the real-time communication and collaboration in the same period of time [2]. For example, in Xi'an International University, students and teachers are allowed to access to the network teaching resources using their own account and achieve hyperspace, real-time communication in the concrete resources channels through the humanized operations. With this type of real-time communication, learners are promoted to learn and deeply rethink teaching and learning activities, so as to meet the inner sense of belonging and identity. 
4. The current situation and problems of applying network teaching platform to the teaching of course Management Science in Xi'an International University

The network teaching resources platform has been opened by Xi'an International University and there have been a great number of quality teaching resources related to Management Science. However, seen from the current situation, the effect is unsatisfactory, and the specific problems are as follows.

\subsection{Unsatisfactory combination of Management Science teaching with network resource platform}

At present, the traditional teaching model is still adopted by all teachers, because a unified teaching plan has not been agreed yet for how to combine Management Science teaching with network teaching resource system in this school. Most teachers aim to download the related Management Science teaching videos and browse the excellent course construction of other schools from the teaching resources platform. In other words, they take advantage of the network resources only for improving the personal teaching quality and have no more progresses.

\subsection{Network teaching resources are rarely used by students in learning Management Science}

For the students, the network teaching resources platform did not play a good role. According to a preliminary investigation, the students' understanding of network teaching platform system was not comprehensive, and some even never logged in the system. The students logging in the system only stayed in the state of blind viewing. Therefore, Management Science and network teaching platform are two separate and independent parts, and the advantages of network teaching platform do not make the teaching of Management Science truly displayed.
5. Several suggestions on the application of network teaching platform to the teaching of Management Science

\subsection{Fully realizing the importance of network teaching platform to the teaching of Management Science}

Network teaching is of great significance in stimulating students' interest in learning, improving the students' self-study competence, supplementing teaching resources, expanding the management knowledge areas, breaking the traditional teaching model, enhancing the teaching quality, and promoting the change of course teaching methods. Therefore, great importance is necessarily attached to the network teaching of Management Science. Only in this way, an effective combination of the teaching of Management Science with network teaching will be prompted truly inwardly and behaviorally.

\subsection{Actively exploring a Management Science network teaching platform technical solution that is advanced, rich in contents, and easy to use}

The network teaching platform for course Management Science is a basic construction. In the early stage of the construction, therefore, a Management Science network teaching platform technical solution that is advanced, rich in contents, and easy to use is necessarily available. To set up and improve this technical solution, the expert opinions from different areas and even the opinions of students are necessarily absorbed and repeatedly demonstrated [3].

5.3 Attaching the dynamic combination of the Management Science network teaching platform construction with training, development, application and evaluation

To set up a network course on network teaching platform is a huge workload, which requires teachers to expand a lot of time and energy and is 2-3 times the traditional teaching workload. But 
the workload for developing network resources is 3-4 times that of compiling the paper-based textbooks with the same contents [4]. These great workload and energy are necessarily affirmed and recognized by school leaders. Therefore, schools need to carry out training for teachers according to the characteristics, functions and methods of the established network teaching platform, so that teachers can get a full understanding of how to effectively teaching with the aid of network teaching platform, and simultaneously students can know how to make use of network teaching platform for autonomous learning. Therefore, developing new applications of network teaching, digital teaching resources, and information-based teaching pattern is necessarily incorporated into the school teaching reform projects.

\subsection{Providing financial supports}

Through project developments and financial supports, the enthusiasm of teachers can be effectively stimulated for the construction of the Management Science network teaching platform, and then impetus is added to the application of network teaching. Meanwhile, the appropriation budgets for this aspect can be increased by schools so as to provide effective protections for updating, supplementing, improving, and maintaining network teaching platform.

\section{Conclusion}

Along with the development of information technology, especially the development of network technology, a new teaching model (network teaching) has accessed to every aspect of the modern education. As a carrier of the network teaching, network teaching platform arises at the historic moment and also is developing at very fast speed. With the application of network teaching platform, the purpose of greatly enriching teaching methods, expanding teaching space, and balancing teaching resources will be achieved.

\section{Acknowledgement}

This paper financially aided by the Education Science "Twelfth Five-year" Plan 2014 of Shaanxi Province, "Study on the Teaching Reform of Course Management Science based on the Applied Talents Training in Private Higher Learning Institutions" (No.SGH140872). This paper was also a follow-up result of Xi'an International University's Course Management Science to win the Annual Excellent Course Praise of Shaanxi Province in 2013.

\section{References}

[1] Ling HE, Xiping WANG, Shuwen LIU. The Application of Network Integrated Platform to Major Courses [J]. Education Forum, 2014, (1).

[2] Yu GAO. Analysis on the Advantages of network Instruction in English Education [J]. Jiannan literature, 2011, (9).

[3] Shidong GAO, et al. Web-based Instruction Questionnaire Design and Analysis - the Questionnaire of Beijing University's Network Teaching Platform Application is taken for Example [J]. Teaching and Research, 2014, (1).

[4] Junqi HOU, et al. Study on the Application of network teaching platform in Management Teaching [J]. Value Engineering, 2011, (28). 